\title{
Discourse Analysis of Lessons on Mitosis, Meiosis and Classification of Living Organisms at Selected Secondary Schools in Luapula Province, Zambia
}

\author{
Kambi Manda*, Christopher Haambokoma, Kabunga Nachiyunde \\ Mathematics and Science Education Department, University of Zambia, Lusaka, Zambia
}

*Corresponding Author: Kambi Manda, Mathematics and Science Education Department, University of Zambia, Lusaka, Zambia

\begin{abstract}
This paper explores classroom discourse patterns of lessons on topics perceived to be difficult in biology such as classification, mitosis and meiosis at senior secondary school level. A collective case study design was used and data were obtained from pupils and teachers using observation schedules and interview guides. Data collected were analysed using discourse analysis and thematic analysis. The study found that three discourse patterns are used by teachers when teaching topics perceived to be difficult in biology. These discourse patterns include teacher explanation discourse pattern, teacher led discourse pattern and pupil to pupil discourse pattern. The effects of these discourse patterns are that pupils and teachers find it difficult to explain stages of cell division and classification of living organisms. In view of the findings above, the following recommendations are made; Teachers should combine the three discourse patterns when teaching topics perceived to be difficult in biology. Teachers should avoid teaching using one discourse pattern when teaching topics perceived to be difficult in biology. Workshops and seminars should be organised for teachers in order for them to improve their skills on the use of these three discourse patterns.
\end{abstract}

Keywords: Discourse patterns, classification, mitosis, meiosis, biological terms, cell division, practical activities, difficult topics.

\section{INTRODUCTION}

Although the general view is that biology is the easiest science subject to learn (Haambokoma, 2007), examination results indicate that many candidates fail biology at the end of grade 12 (ECZ, 2016).

This countrywide underachievement of pupils in biology is not new. For example in 2002 a total of $9975(52.5 \%)$ pupils failed biology out of a total of 19000 registered candidates. In 2003 again 11890 (58\%) pupils failed biology out of a total of 20500 registered candidates (ECZ, 2004).

One possible reason for this underachievement is that some pupils and teachers find some topics difficult to learn and teach respectively. According to the baseline study which was conducted by Haambokoma el at (2002), sometopics were identified to be difficult to both teachers and pupils such as genetics, ecology, coordination and diversity of living organisms.However, classroom discourse patterns during lessons on topics perceived to be difficult have not been examined in Luapula province.

\subsection{Statement of the Problem}

Although researchers (e.g Abimbola, 1998; Haambokoma et al, 2002; Cimer, 2012; Musonda, 2013; Chocha, Namayanga \& Ndhlovu, 2014, Chifwa, 2015) have identified topics perceived to be difficult in biology, for both teachers and learners, no studies have been conducted in Zambia to achieve knowledge and understanding of classroom discourse patterns during biology lessons on these perceived difficult topics in secondary schools in Luapula Province. Hence there is no knowledge on this issue of classroom discourse patterns which needed investigation.

\subsection{Purpose of the Study}

The main purpose of this qualitative study was to achieve knowledge and understanding of classroom discourse patterns during lessons on topics perceived to be difficult in biology at senior secondary school level in selected secondary schools in Luapula Province of Zambia. 


\subsection{Research Objectives}

The objectives of the study were as follows:

1. To analyse the classroom discourse patterns during lessons involving topics perceived to be difficult in biology.

2. To explore what could be done to improve the teaching and learning of topics perceived to be difficult in biology in order to facilitate pupils' understanding.

\subsection{Research Questions}

The study was guided by the following questions:

1. How are the classroom discourse patterns during lessons involving topics perceived to be difficult in biology?

2. What could be done to improve the teaching and learning of topics perceived to be difficult in biology in order to facilitate pupils' understanding?

\subsection{Significance of the Study}

There are no studies to the researcher's knowledge which have been undertaken to analyse classroom discourse patterns during lessons involving topics perceived to be difficult in biology and what underpins the choice of discourse patterns used to teach perceived difficult topics in biology in Luapula province. This study is, therefore important in many ways; firstly it has generated new knowledge which will help to understand classroom discourse patterns during lessons involving topics perceived to be difficult in biology.

Secondly, this study has generated information which could be used by various stakeholders by providing an empirical basis for decision making regarding improvement of biology education in secondary schools, colleges and universities.

Furthermore, information generated from this study will assist science teacher educators involved in the preparation of teachers of biology for possible improvement in pedagogy. Heads of Science Departments will be helped in allocating more time to perceived difficult topics when preparing schemes of work. School Administrators will be assisted when soliciting for teachers of biology. Textbook Writers will be helped to simplify their work as they develop textbooks for pupils and teachers. Science Standard Officers will be helped to advice teachers of biology as they observe them. Curriculum Developers will be helped to pay attention to perceived difficult topics as they develop biology materials for teachers and pupils and the Examination Council of Zambia will be assisted to consider perceived difficult topics when preparing final examinations.

Other researchers may find the knowledge which has been generated to be important as a source of information for further research.

\subsection{Theoretical Frameworks}

This study was informed by two theoretical perspectives, namely, Expectancy Value Theory (Eccles et al, 2002) which has some relevance on choices people make and the Transactional Model of the teaching and learning process developed by Huitt (1995) which explains the factors affecting teaching and learning.

\subsubsection{Expectancy-Value Theory}

According to the Expectancy - Value Theory, choices which people make are influenced by two beliefs which are the expectancy of achievement belief and the task value belief. According to this theory teachers choose particular discourse patterns were they expect to enjoy and be successful. Their choices also depend on important, useful and cost effective discourse patterns (Stuart \& Whaley, 2005).

Below is a modified diagrammatic representation of Eccles et al, (2002) Expectancy- Value Theory. 
Discourse Analysis of Lessons on Mitosis, Meiosis and Classification of Living Organisms at Selected Secondary Schools in Luapula Province, Zambia

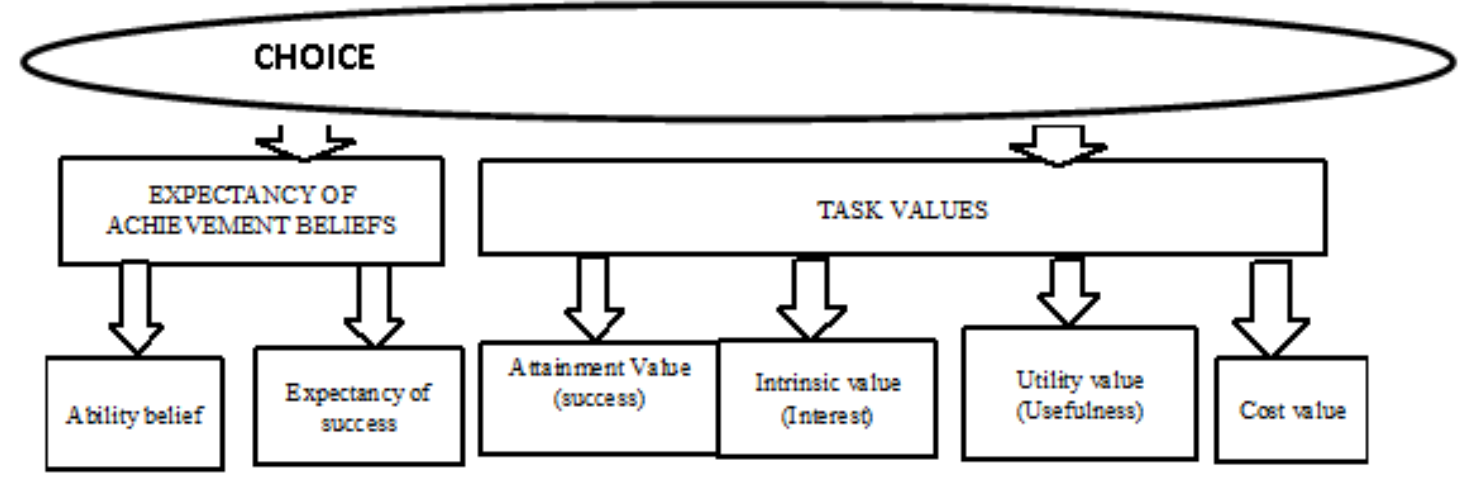

Figure1. Expectancy - Value Theory as adapted from Eccles et al (2002)

The two beliefs of the Expectancy-Value Theory are explained in table 1.

Table1. Expectancy-Value Theory beliefs

\begin{tabular}{|l|l|}
\hline Expectancy of $\begin{array}{l}\text { of } \\
\text { achievement beliefs }\end{array}$ & $\begin{array}{l}\text { Ability beliefs- The ability to perform on a task } \\
\text { Expectance of success- A persons belief about how well he or she will perform on } \\
\text { an upcoming task }\end{array}$ \\
\hline \multirow{3}{*}{ Task values } & Attainment value (success)- Importance of succeeding on a task \\
\cline { 2 - 2 } & $\begin{array}{l}\text { Intrinsic value (interest)- The pleasure a person derives from participating in an } \\
\text { activity }\end{array}$ \\
\cline { 2 - 2 } & Utility value (Usefulness)- The benefits a person will derive from performing an activity \\
\cline { 2 - 2 } & Cost value- The savings a person will realise by participating in an activity. \\
\hline
\end{tabular}

Source: Eccles et al (2002)

The Expectancy- Value Theory was initially used to understand why there are few females in science related careers (Eccles, Jacobs \& Harold, 1990; Eccles, Baber \& Jozefowiez, 1999). It has also been used to study choices pupils make to study mathematics in high school and beyond high school (Wigfield, 1994). It has further been used to study decisions people make in taking certain subjects such as physical education (Xian et al, 2003) and to study enrolment decisions people make in science courses (Barnes, Mc Inerney \& Marsh, 2005). Haambokoma (2015) also used this theory to study what motivated girls to get involved in JETS activities in selected Zambian schools. One strength of this theory is that it is based on extensive empirical studies undertaken in different countries of the world. However, one limitation is that this theory emerged from studies conducted in the developed parts of the world. Therefore the factors affecting the choice of discourse patterns in the Zambian classrooms may be different from those of advanced nations.

Nevertheless, the beliefs highlighted by this theory will be used to discuss the choice of discourse patterns used by teachers during lessons on topics perceived to be difficult in biology because they are similar.

\subsubsection{Transaction Model}

The Transaction Model developed by Huitt (1995) classified factors affecting output (which is pupils learning achievement) into three categories namely; context, input and classroom processes. Context covers all the factors outside the classroom that might influence teaching and learning such as social economic status and state policies. Input covers those qualities or characteristics of teachers and students that they bring with them to the classroom experience such as previous knowledge about the subject matter. Classroom processes include teacher and student behaviours in the classroom as well as some other variables such as classroom climate and teacher and student relationships (Huitt, 1995).

The role of the teacher in terms of facilitation of learning by specifying the lesson objectives, selecting groups of pupils and their roles in groups and in monitoring the effectiveness of the groups was the focus of the open ended questionnaires and interview schedules. The use of learners' own responses also guided the analysis and interpretation of the findings.

According to the transactional model, the factors affecting learning can be classified into four categories 
Discourse Analysis of Lessons on Mitosis, Meiosis and Classification of Living Organisms at Selected Secondary Schools in Luapula Province, Zambia

Table2. A Transaction Model of the Teaching and Learning Process

\begin{tabular}{|l|l|}
\hline Context & $\begin{array}{l}\text { All those factors outside of the classroom that might influence teaching and learning such as } \\
\text { social economic status and state policies }\end{array}$ \\
\hline Input & $\begin{array}{l}\text { Those qualities or characteristics of teachers and students that they bring with them to the } \\
\text { classroom experience such as previous knowledge about the subject matter }\end{array}$ \\
\hline $\begin{array}{l}\text { Classroom } \\
\text { Processes }\end{array}$ & $\begin{array}{l}\text { Teacher and student behaviours in the classroom as well as some other variables such as } \\
\text { classroom climate and teacher/student relationship. }\end{array}$ \\
\hline Output & Measures of student learning like examination results. \\
\hline
\end{tabular}

Source: Huitt, (1995)

The transaction model has weaknesses because it ignores the variations which exist between different subjects and it is also based on studies done outside Zambia. The most important category on the transaction model is output because once that has been defined it explains the importance of the variables in the other categories (Huitt, 1995). For example, if the desired outcome measure is a score on a standardised test of basic skills, the instructional method most likely to positively impact that measure is direct or explicit instruction (Rosenshine, 1995). However, if the desired outcome is creativity and independence, then the teacher led instruction may be a better alternative (Giaconia \& Hedges, 1982). Alternately, if a better relationship among diverse students is the goal, the cooperative learning would appear to be the better instructional method (Slavin, 1995). Although the transaction model has some weaknesses which are given above, it is useful to this study in that it provides some guidance on what influences classroom discourse patterns during biology lessons. The transaction model was also used by Mwiya, 2015 in his study when he was looking at the classroom performance of graduate and non- graduate biology teachers in selected secondary schools in Lusaka district of Zambia.

Below is the diagrammatic representation of the modified transaction model

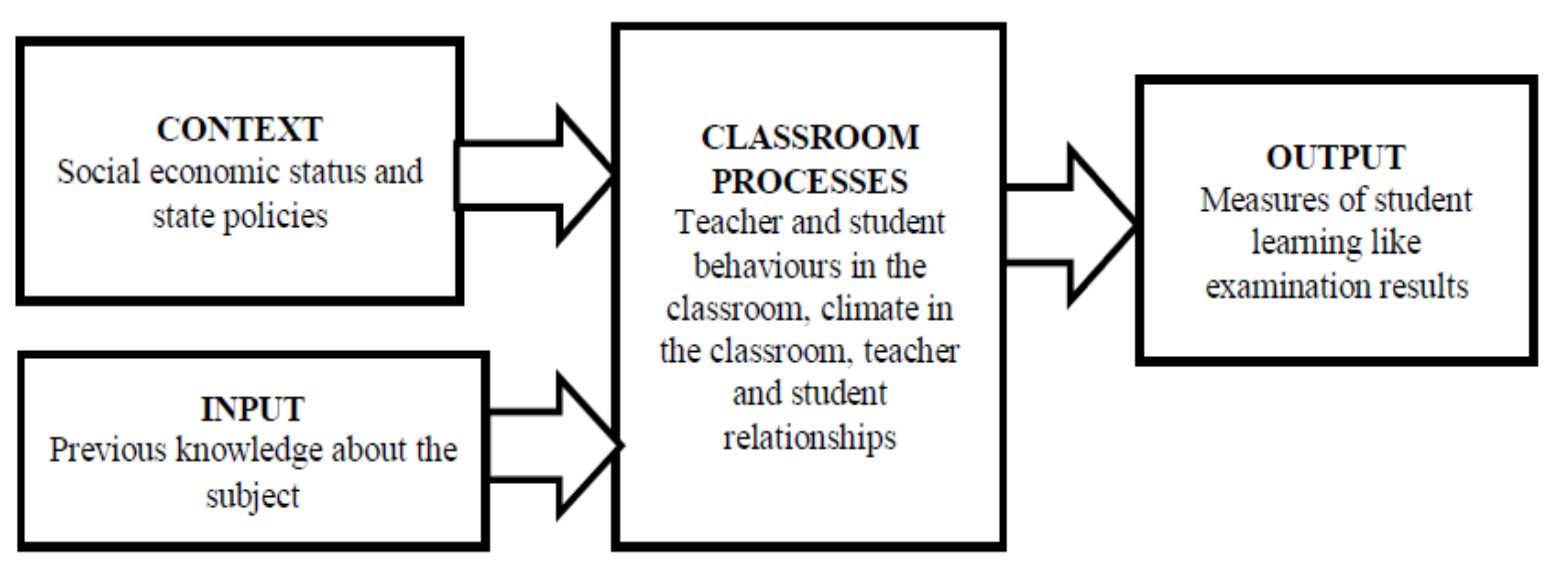

Figure2. Transaction modelas adapted from Huitt (1995)

Other researchers who have used more than one theoretical perspectives include Kaulu (2015) whose study on student misconceptions in physics education was informed by two cognitive constructivist theories of learning as interpreted and applied to science education by Kelly (1966), and Von Glasersfeld (1995) because they had common premises which guided the research. Another study Haambokoma (2015) on influences of female pupils decision to join the Junior Engineers Technicians and Scientists club in Zambia was informed by three theoretical perspectives namely, the Feminist Theory, the Self-Efficacy Theory and the Expectancy-Value Theory because they had some relevance on decisions or choices people make. Therefore it was appropriate to use two theoretical perspectives because they guided the current study on classroom discourse patterns.

\subsection{Conceptual Framework}

Knowledge development by students themselves in class is mainly demonstrated by verbal means through classroom discourse. However, students' verbal expression of their views depends on teacher questions or statements that elicit either answers or responses from students (Beccles, 2012). This study is underpinned by the view of teaching and learning as a relationship between an individual learner, the instruction, lesson content, the learning outcome and the teacher. 


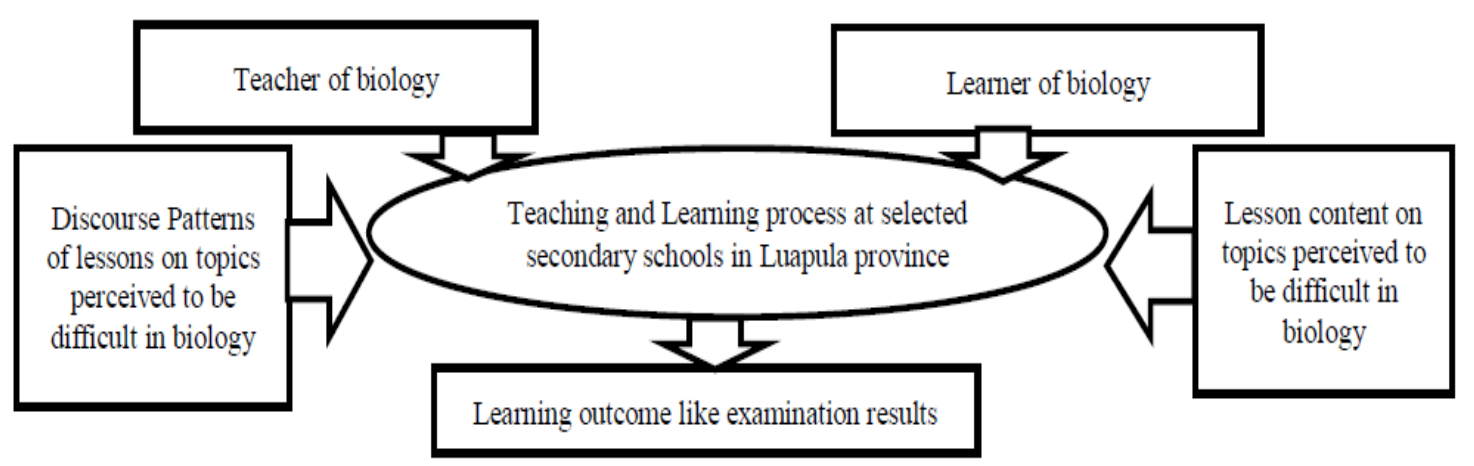

Figure3. Conceptual framework

\section{Methodology}

A qualitative research approach which focused on a collective case study was used in this study to acquire understanding of classroom discourse patterns during lessons involving topics perceived to be difficult.

The study was conducted at 4 secondary schools in Luapula province which had poor school certificate results for 2015 and whose pseudo names and actual school certificate pass percentages are: Mango had 47\%, Orange had 46.6\%, Lemon had 42.8\% and Apple had 41.3\% (PEO Mansa, 2016).

The study population was all senior secondary school pupils learning biology and all teachers of biology.

At each school only 10 pupils were selected to participate in the focus group discussions of the study. This means that a total of 40 pupils participated in the study. A total of 11 teachers were selected from the four schools, three teachers from three schools and two teachers from one school. The sample size is usually small in a qualitative study (Merriam, 1998).

Senior secondary school pupils were selected using purposive sampling. Teachers of biology were selected on the basis of availability and willingness to participate in the study. Eleven Lessons observed were also purposively sampled.

Semi-structured interview guides and lesson observation schedules were used to collect data

Data collection was preceded by a pilot study at Lubwe secondary school in Samfya District of Luapula Province to check on the suitability of research instruments and data collection procedures.

Trustworthiness was achieved through prolonged field work and recording interviews as well as filming lessons.

Data analysis took place concurrently with data collection as advised by Creswell (2003). Data collected from interviews was analysed using thematic analysis approach (Kombo \& Tromp, 2006). Lesson observations were analysed using discourse analysis (Louis, Lawrence \& Keith, 2000).

Ethical issues were put into consideration such as seeking permission from participants before recording interviews and filming lessons. In addition, actual names of the participants and their schools have not been revealed in the report as recommended by Creswell (2003).

\section{RESUlts}

Eleven lessons were observed in this study but only three lessons were selected for this paper to answer the following research question: How are the classroom discourse patterns during lessons involving topics perceived to be difficult in biology?

\subsection{Lesson One on Mitosis}

The teacher's questions in this lesson required pupils to give a word or short sentence, which is not good for encouraging substantive student discourse in the classroom. The introductory part of the lesson took 10 minutes. The teacher took 80 minutes to conclude this lesson.

Below is an excerpt of the introduction to the lesson on one of the types of cell division known as Mitosis. 
Discourse Analysis of Lessons on Mitosis, Meiosis and Classification of Living Organisms at Selected Secondary Schools in Luapula Province, Zambia

Teacher: What is cell division?

Pupil 1: Cell Division is a process by which new cells are formed from already existing cells

Teacher: Can you mention the two types of cell division?

Pupil 1: Mitosis

Pupil 2: Meiosis

Teacher: What is Mitosis?

Pupil 1: Cell division which occurs in the body cells

Teacher: Others, what do you have to say?

Pupil 3: Two identical cells are produced from a zygote mother

Teacher: Others

Pupil 4: Mitosis is a type of cell division where 2 diploid and genetically identical cells are produced from one mother cell.

The teacher was supposed to clearly guide the pupils to describe mitosis as a type of cell division which takes place in all cells, except sex cells. The teacher should have asked pupils to explain that cells other than sex cells are called somatic cells. The teacher also forgot to emphasise that mitosis results in two cells that are identical to the original.

The main part of the lesson took 60 minutes and proceeded as shown by the following excerpts.

Teacher: Mention 4 stages of mitosis

Pupil 5: Prophase

Pupil 6: Metaphase

Pupil 7: Anaphase

Pupil 8: Telophase

After each response the teacher restated the answer in order to appreciate the pupils' response. This was the only way the teacher appreciated pupil's responses.

Thereafter the teacher divided the class into four groups to discuss thefour stages of Mitosis. The teacher encouraged the pupils to use the books they had on their desks. After ten minutes the teacher asked the group leaders to present their findings. This time was not enough for pupils to complete their work in groups. During group work, the teacher was moving from one group to another facilitating the group discussions by resolving issues pupil did not understand. Pupils were seen interacting with each other in the groups. At the beginning of group discussions the teacher distributed worksheets showing different stages of mitosis for pupils to look at before describing the stages of mitosis in their groups. This worksheet shows different stages of the process of mitosis in Figure 4;

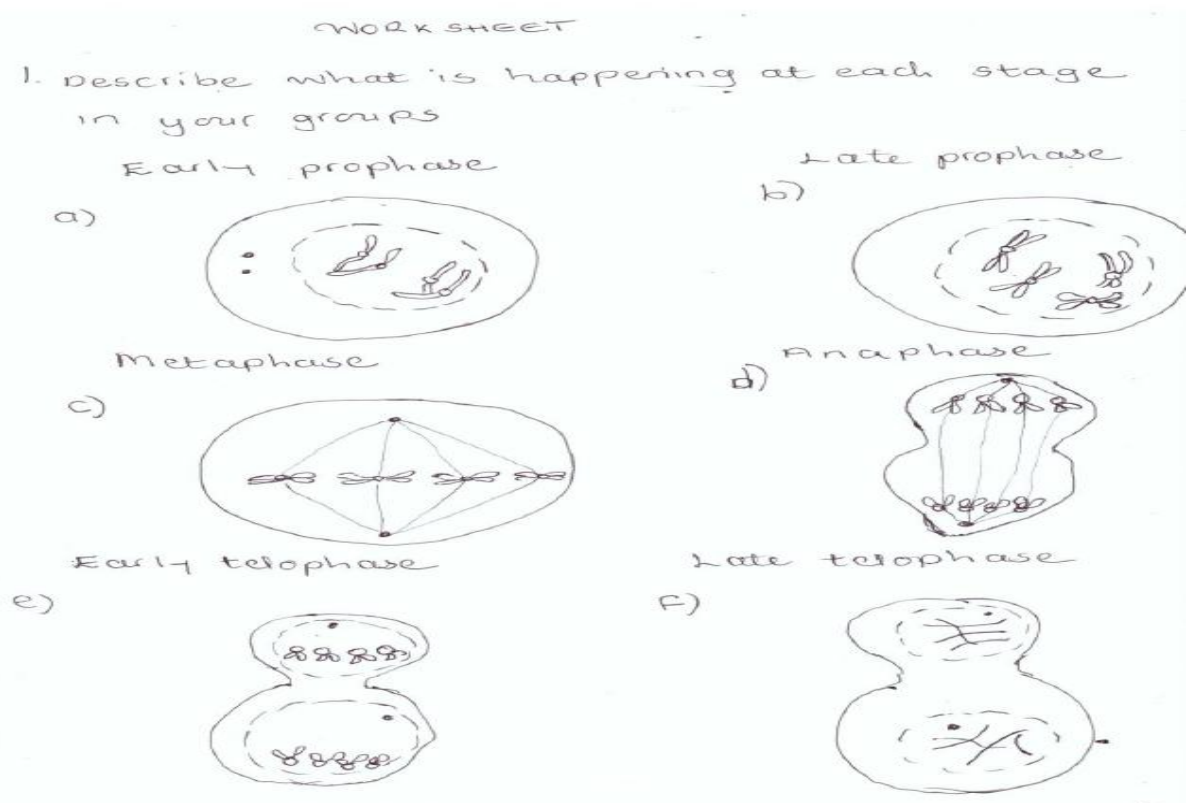

Figure4. Worksheet showing stages of mitosis 
In this worksheet the teacher asked group one to do exercise one (a) and (b) on prophase, group two was told to describe what was happening at one (c) on metaphase, group three was given one (d) on anaphase and group 4 was told to describe what was happening at one (e) and (f) on telophase.

Report From Group One on Prophase: Pupils were expected to state what happens to the cell during prophase. The group representative stated the following statements from their discussion.

\section{The cell divides itself to perform its functions \\ Chromosomes shorten and thicken to become visible \\ Connected at the centromere, each chromosomes is now seen to contain 2 strands \\ Nuclear membrane and nucleus disappear making the end of prophase}

After this presentation the teacher extended the pupils presentation and guided the pupils in this group by saying that they were expected to report that during early prophase, the chromosomes become visible in the nucleus as the threads of the chromatin network become shorter and thicker. During late prophase, the chromatids become visible. They are held together by a centromere. The centrioles move to opposite ends of the cell and spindle fibres begin to form between them. The good thing about this is that the pupils knew that chromosomes became visible by shortening and thickening, but they did not know where this was happening within the cell. The teacher reminded them that the process of shortening and thickening of the chromosomes was happening in the nucleus.

Report From Group Two on Metaphase: In this group pupils were expected to explain what happens during metaphase. The group representative reported the following from their group discussion:

\section{The chromosomes line up along the equator \\ The spindle fibres attach themselves to the centromere of the chromosomes}

This group explained exactly what happens during metaphase because they were able to explain that chromosomes line up in the centre of the cell on an imaginary line called the equator and that chromosomes attach to the spindle fibres.

Report From Group Three on Anaphase: Pupils were expected to describe what happens to the cell during anaphase. The group representative made one statement in his presentation as follows:

Sister chromatids are separated from each other and pulled from each other.

This group was supposed to report that during anaphase the spindle fibres contract and pull the chromatids towards the opposite ends of the cell called poles. Pupils in this group did not know what was pulling the chromatids away from each other. This was pointed out by the teacher when she said that the contraction of spindle fibres assisted in the separation of the chromatids from each other.

Report From Group Four on Telophase: Pupils were expected to explain what happens to the cell during telophase. The statements below were reported from the group discussion by the group representative.

Chromatids reach the poles of the cells and align to form chromatin again.

Nuclear membrane reappears

Spindle fibres disappear.

Pupils in this group were supposed to explain that during early telophase the chromatids reach the poles and a new nuclear membrane starts to form around them. Spindle fibres break down. The pupils were also supposed to show that during late telophase the chromatids are now called chromosomes and they unwind becoming long threads and finally each new nucleus contains chromosomes identical to the parent chromosomes.

The teacher restated and even extended group representatives responses and explanations. This was done to appreciate the pupils and motivate them. The teacher did not ask other pupils to react to their group representatives' presentations. According to her she thought it was time wasting. She put it this way:

I did not allow pupils to react to their group representative's presentations because I thought it was just wasting time. 
The teacher described the stages of mitosis to help make statements pupils made during group work presentations very clear as follows;

\section{Prophase Stage}

Centrioles move to opposite poles

Spindle fibres appear from centrioles.

Nuclear membrane and nucleolus disappear.

Chromosomes coil and shorten becoming visible.

\section{Metaphase Stage}

Chromosomes line up along the equator

Spindle fibres attach themselves to centromere of chromosomes

\section{Anaphase Stage}

Sister Chromatids are separated from each other and pulled to opposite poles, centromeres first.

\section{Telophase Stage}

Chromatids reach the poles of the cell uncoil and lengthen to form chromatin again.

Spindle fibres disappear.

Nucleolus and Nuclear membrane reappear.

The teacher should have guided the pupils to explain that the preparation for cell division occurs in a stage called interphase and that at the end of interphase the cell nucleus and cytoplasm are ready to divide. However, the teacher ruled out the fact that mitosis starts with interphase and went on to emphasise that mitosis starts with prophase. This statement was not correct.

In order to conclude the lesson the teacher explained that mitosis is very important to living organisms. The excerpt below shows how the teacher concluded the lesson within ten minutes.

Teacher A: Why is mitosis important to living organisms?

Pupil 1: It is needed for growth

Teacher A: Another way in which mitosis is important to living organisms

Pupil 2: Replacement of cells

Teacher A: Another way

Pupil 3: Asexual reproduction

Pupil 4: To maintain stability

Pupil 5: Regeneration

Teacher A: What is regeneration?

Pupil 6: Continuity of the same characteristics of the cell.

Pupil 7: Regeneration is another type of asexual reproduction.

Pupil 1: Does mitosis occur in plants or Animals?

Teacher A: It occurs in both plants and Animals.

Pupils only understood the importance of mitosis and this was seen from the number of participants who wanted to contribute when the teacher asked the class to state the importance of mitosis. The teacher concluded the lesson by restating the importance of mitosis to living organisms.

Only eight pupils were answering questions from the teacher except when he asked on the importance of mitosis, the rest were just quiet and the teacher did not bother to even point at them to give answers. The teacher was only pointing at pupils who had raised their hands to contribute to the lesson by answering questions. The discourse patterns which emerged from this lesson were three, namely the teacher led, pupil to pupil and the teacher explanation. This lesson combined all the three discourse patterns which were dominated by the teacher led and this raised pupils' morale towards the 
end of the lesson as almost every pupil wanted to contribute to the importance of mitosis during the question and answer session of the concluding remarks. This lesson started with the teacher asking a series of questions. The teacher's questions in this lesson required pupils to give a word or short sentence, which is not good for encouraging substantive student discourse in the classroom. Later on during the lesson the teacher divided the class into groups where they discussed the stages of mitosis. After group presentations the teacher again explained further the stages of mitosis.

\subsection{Lesson Two on Meiosis}

The duration of this lesson was 80 minutes. The teacher spent 11 minutes to introduce the lesson. Below is an excerpt for the lesson introduction.

Teacher E: How many types of cell division do we have?

Pupil 1: They are two

Teacher E: What are they?

Pupil 2: Mitosis and Meiosis

Teacher E: What is Mitosis?

Pupil 3: The type of cell division where the number of chromosomes of the parents is equal to the number of chromosomes in the daughter cells.

Pupil 4: Process by which new daughter cells are produced from the mother cells with the diploid number of chromosomes.

Teacher E: Another one to try

Pupil 5: It is a type of cell division where two genetically identical daughter cells are produced.

Teacher E: In which type of body cells does mitosis occur?

Pupil 5: Somatic cells

Teacher E: What are somatic cells?

Pupil 4: Somatic cells are all these other cells apart from the gametes

Teacher E: What type of cell division occurs in the gametes?

Pupil 5: Meiosis

Teacher E: Today we are going to look at meiosis. What is meiosis?

Pupil 6: It is the type of cell division where gametes are produced and they maintain a number of haploid chromosomes.

Teacher E: Others

Pupil 5: It is a type of cell division which takes place in the reproductive organs to produce reproductive cells or gametes.

Pupil 7: It is a type of cell division where by one parent produces 4 daughter cells which are not genetically identical.

Teacher E: What is meant by the term haploid?

Pupil 7: Daughter cells having half the number of chromosomes.

Teacher E: Which symbol do we use for haploid?

Pupil 8: $n$

The teacher explained that each human being has 23 pairs of chromosomes.

Teacher E: What are the stages of meiosis?

Pupil 4: The first stage is prophase I followed by metaphase I then anaphase I and telophase 1. 
Discourse Analysis of Lessons on Mitosis, Meiosis and Classification of Living Organisms at Selected Secondary Schools in Luapula Province, Zambia

The teacher emphasised that meiosis involves two divisions which are the first and second meiotic division.

The teacher divided the class into four groups to do an activity of describing the two types of meiotic divisions. The teacher distributed pictures of diagrams involving the two meiotic divisions. Each group was expected to examine the two meiotic divisions. The worksheet which was given to the pupils in groups is shown as Figures 5,6,7 and 8.



Figure5. Instructions and questions for the group work

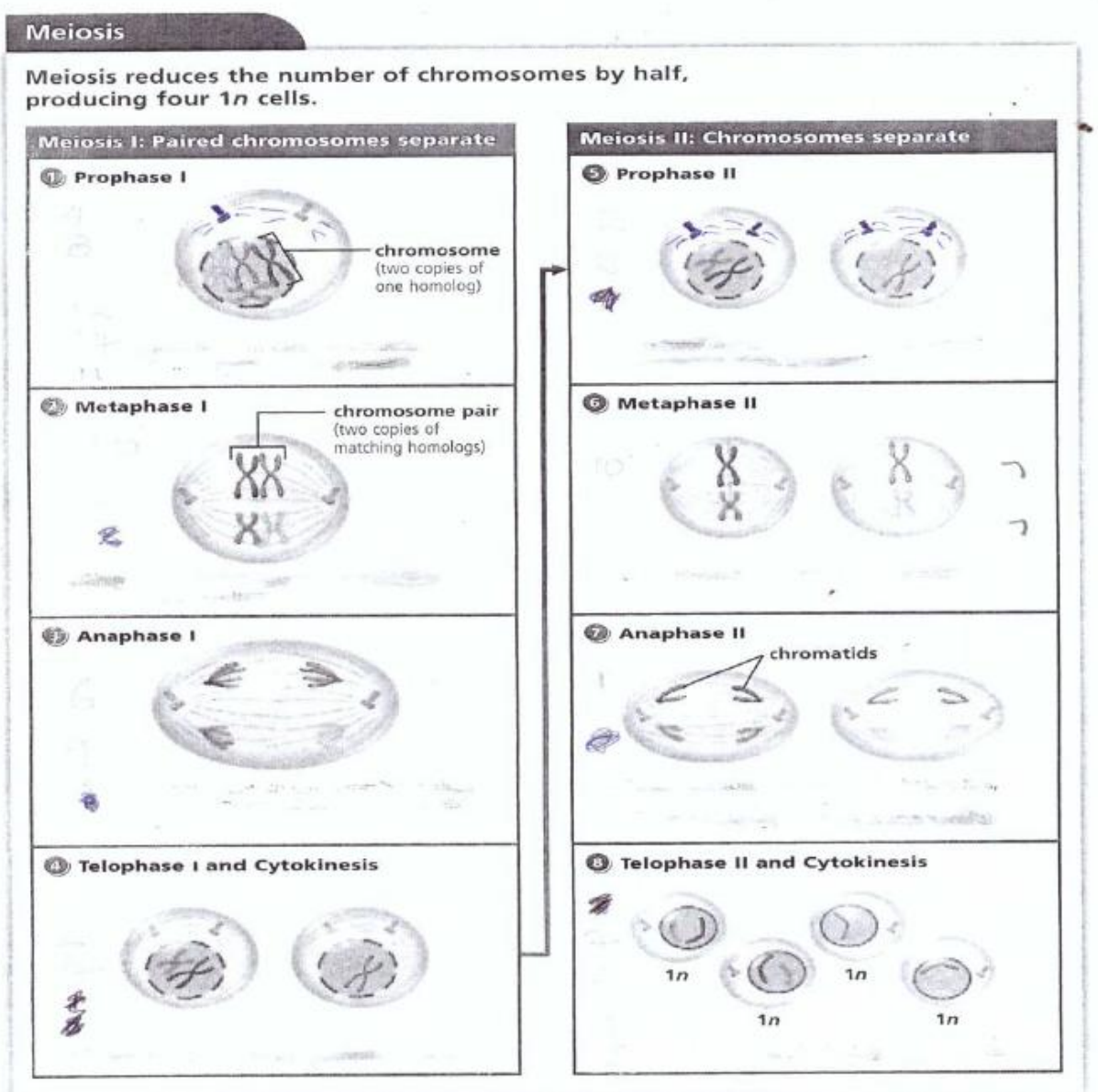

Figure6. Diagrams showing stages of meiosis I and meiosis II 
Discourse Analysis of Lessons on Mitosis, Meiosis and Classification of Living Organisms at Selected Secondary Schools in Luapula Province, Zambia

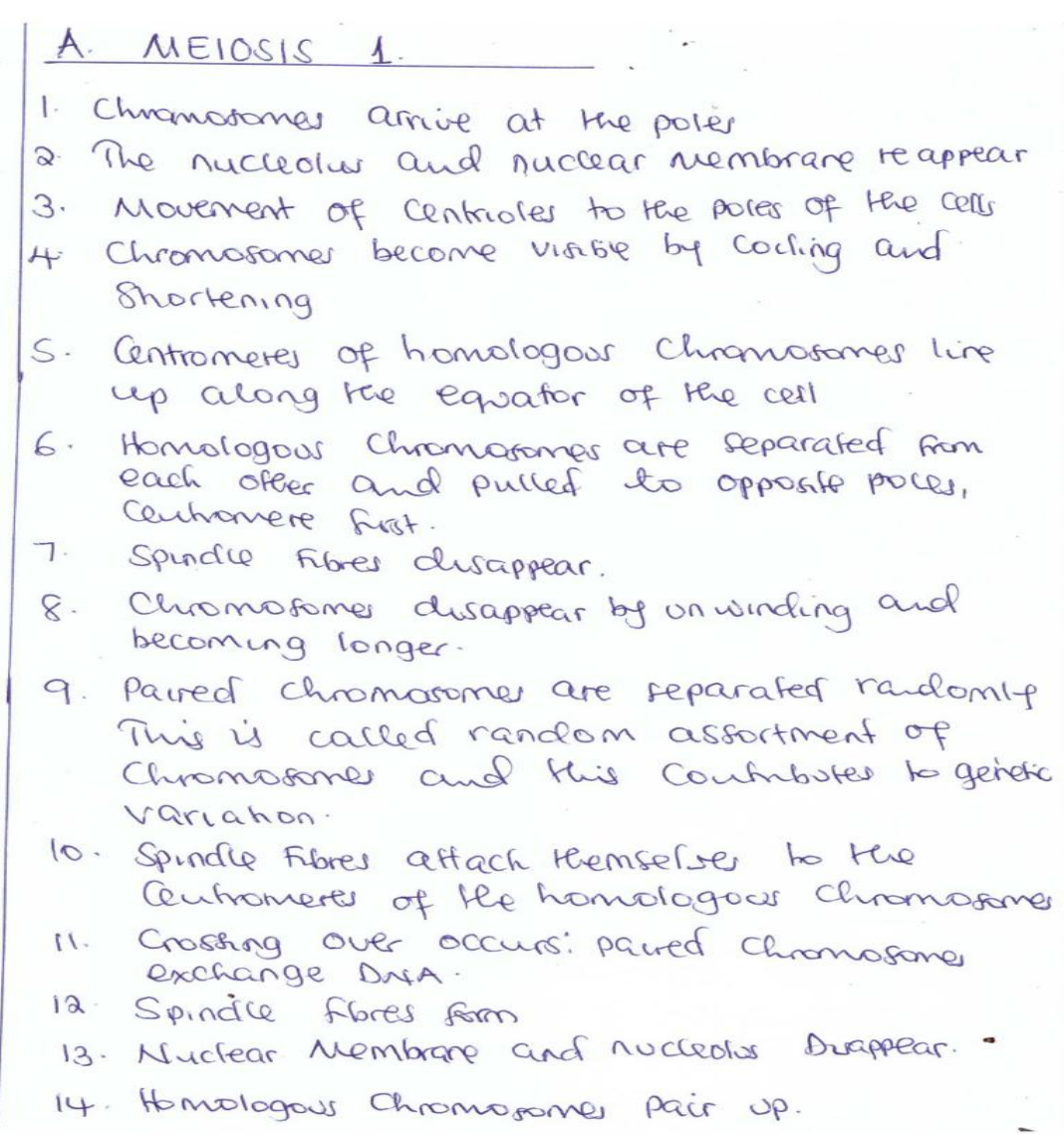

Figure7. Descriptions of meiosis I

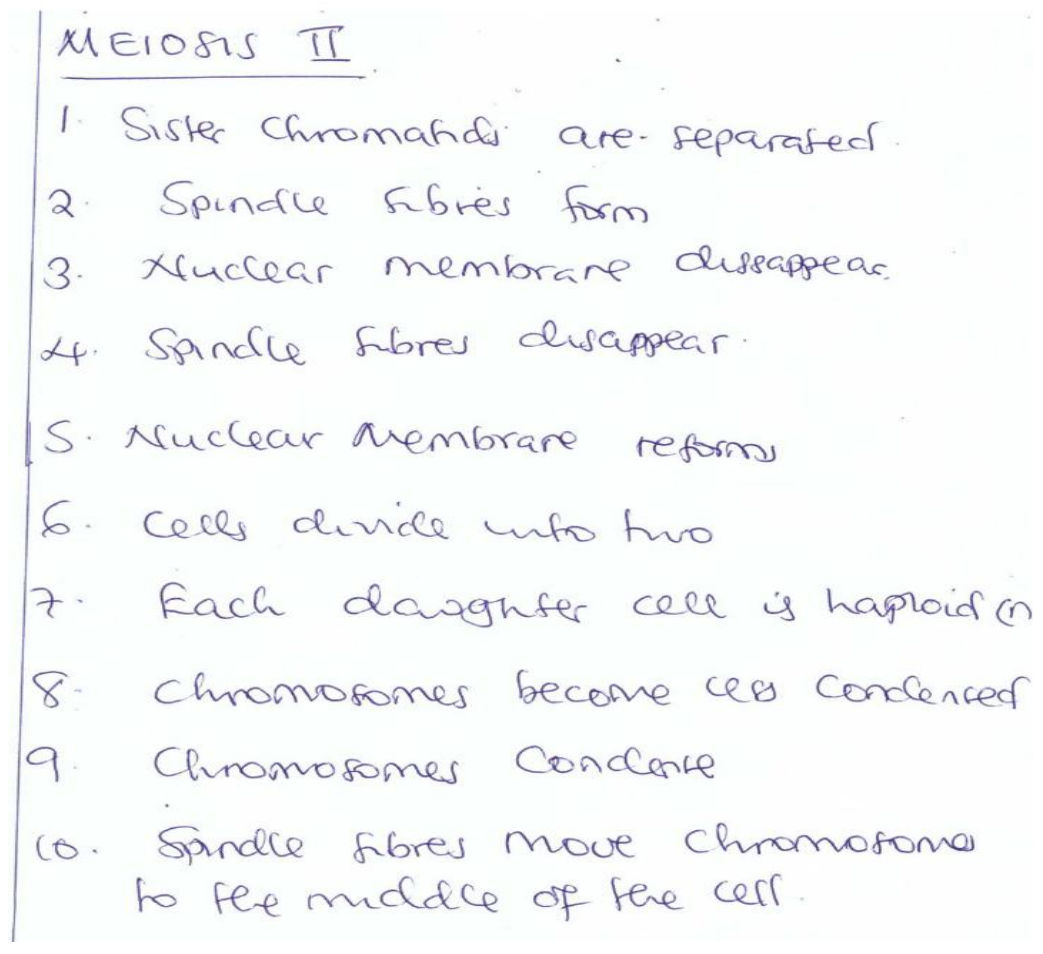

Figure8. Descriptions of meiosis II

After 15 minutes group leaders were asked to report their findings.

\section{Group One}

This group reported on prophase I. They said that:

Chromosomes become visible by coiling and shortening. 
There is movement of centrioles to the poles of the cells.

Nuclear membrane and nucleolus disappear.

Spindle fibres form.

Homologous chromosomes pair up.

Group one reported correctly about the events occurring under prophase one and the teacher promised to give them an incentive.

\section{Group Two}

This group reported on metaphase I. They said that:

Spindle fibres attach themselves to the centromeres of the homologous chromosomes.

Centromeres of homologous chromosomes line up along the equator of the cell.

Chromosomes arrive at the poles.

Spindle fibres form.

Homologous chromosomes pair up.

Group two only reported the first two events correctly but ended up mixing ideas by including events which occur under prophase such as the formation of spindle fibres and the pairing of homologous chromosomes. They also included an event which occurs under anaphase such as the arrival of chromosomes at the poles.

\section{Group Three}

This group reported on anaphase I. They said that:

Homologous chromosomes are separated from each other and pulled to opposite poles centromere first.

There is movement of centrioles to the poles of the cells.

Chromosomes arrive at the poles.

Group three reported wrongly two events namely the movement of centrioles to the poles of the cells and the arrival of chromosomes at the poles. The only statement which group three reported correctly was that homologous chromosomes are separated from each other and pulled to the opposite poles centromere first. The other event they should have included which happens under anaphase I was that paired chromosomes are separated randomly. This is called random assortment of chromosomes and this contributes to genetic variation.

\section{Group Four}

This group reported on telophase I. They said that:

The nucleus and nuclear membrane reappear and also that spindle fibres disappear.

However, they did not include the fact that chromosomes arrive at the poles and that chromosomes disappear by unwinding and becoming longer.

\subsection{Meiosis II}

\section{Group One}

Group one reported the following on prophase II:

Spindle fibres form and that the nuclear membrane disappears.

However, the pupils in this group forgot to include the fact that chromosomes condense.

\section{Group Two}

Group two reported the following about metaphase II:

Spindle fibres move chromosomes to the middle of the cell and this is the only event which occurs during metaphase II. 


\section{Group Three}

Group three reported the following about anaphase II;

Sister chromatids are separated and that chromosomes become less condensed.

However, under anaphase there is only one event which takes place and that is the separation of sister chromatids.

\section{Group Four}

Group four reported the following on telophase II

Spindle fibres disappear and that the nuclear membrane reforms. They also said that cells divide into two.

However, they forgot to include the fact that chromosomes become less condensed.

Before the lesson ended, the teacher gave the pupils an assignment on the importance of meiosis. The discourse patterns which emerged from the lesson were the teacher led and pupil to pupil discourse pattern.

\subsection{Lesson Three on Classification of Living Organisms}

The duration of the lesson was 80 minutes. Below is an excerpt of the lesson introduction which took about ten minutes.

\section{Teacher H: What is classification?}

Pupil 1: Classification is an orderly grouping of organisms according to common features

Teacher H: To which phylum does an earthworm belong?

Pupil 2: Oligochaeta

Teacher H: No

Pupil 3: Nematoda

Teacher H: No

Pupil 4: Annelida

Teacher H: Yes

The correct response was Annelida. However, pupils found it confusing to state the correct phylum due to different classes and phyla. The teacher rejected Oligochaeta because this is the class to which earth worms belong. The teacher also rejected Nematoda because this is another phylum where round worms belong.

The teacher explained that there are various ways of classifying organisms. The teacher said that the common system used by biologists is called natural classification. This is where organisms with similar features are grouped together. The teacher emphasised that when classifying we start with a very general thing.

Teacher H: Do we have cell walls as human beings?

Pupil 2: No

Teacher H: What of Plants do they have cell walls?

Pupil 3: Yes

The teacher further explained that animals with back bones are grouped together in one group and those without backbones are grouped in one group. The teacher said that organisms are arranged from the largest group in descending order to the lowest group. The largest group or unit is the kingdom.

The teacher classified maize as follows:

Kingdom: Plantae

Division: Angiospemophyta

Class : Monocotyledonae

Order: Poales

Family: Poaceae 
Genus: Zea

Species: Zeamays

After classifying a maize plant the teacher said that the smallest unit of classification is species. The teacher reminded pupils that it is difficult to remember the order or family to which an organism belongs. Classification is made easy by developing a dichotomous key.

The teacher gave an example as follows:

Using a dichotomous key below classify the following organisms

(a) Frog (b) Eagle (c) Bat

Stage 1: Warm blooded -4

Cold blooded---2

Stage 2: Has fins but no limbs-Fish

Has 4 Limbs ----3

Stage 3: Has no scales on body- Amphibian

Has Scales -Reptile

Stag4: Has feathers----Bird

Has hairs----Mammal

(a) We start with a frog -it is an amphibian

(b) An eagle is a bird

(c) A bat is a mammal

The teacher did not give reasons why he rejected some answers from pupils and did not even explain why certain answers from pupils were correct. The discourse patterns which emerged from this lesson included teacher led and teacher explanation discourse patterns.

From the lessons observed the study discovered that three discourse patterns are used by teachers of biology when teaching topics perceived to be difficult. These discourse patterns include: Teacher explanation discourse pattern, teacher led discourse and pupil to pupil discourse pattern. In the teacher led discourse pattern the predominant mode was Triple A which is ask, answer, accept and double A and then $\mathrm{R}$ which is ask, answer, reject.

\section{DISCUSSION}

The study set out to investigate classroom discourse patterns of lessons on topics perceived to be difficult in biology at senior secondary school level. It was discovered that three discourse patterns were used when teaching topics perceived to be difficult in biology and these discourse patterns are as follows: Teacher explanation discourse pattern, teacher led discourse pattern and pupil to pupil discourse pattern. The lessons were dominated by the teacher led discourse pattern followed by the teacher explanation discourse pattern and the least used discourse pattern was the pupil to pupil discourse pattern. Introductions and conclusions were teacher led and very brief. Teachers were in most cases using low level questions during the delivery of their lessons, which impacted negatively on the pupils. Most of the lessons were not concluded due to lack of time. Some teachers ended up giving pupils homework as a way of concluding the lessons.

Most of the pupils were not engaged in the discussions during the pupil to pupil discourse pattern. In most cases only group leaders were actively involved since they were seen searching from textbooks and writing a few things to be presented to the class after the discussions. Other pupils were simply observing or doing other things which were not even related to the work which was given to them by the teachers. The study also revealed that classification is not taught practically as a result pupils connect classification with a task of memorising a list of biological names. This is in line with ECZ (2016) where the chief marker reported that pupils fail to use scientific names of locally known plants and animals.

\section{INNOVATION}

In order to come up with a solution to the teaching of difficult topics in biology the researcher looked at the proposals which were advanced by both teachers and pupils and then developed a discourse engagement reference manual which was based on the findings concerning what could be done to 
improve the teaching and learning of topics perceived to be difficult in biology in order to facilitate pupil's understanding.

\subsection{Discourse Engagement in Biology Classrooms: Reference Manual (DEIBC)}

This manual on discourse engagement in biology classrooms has been developed to help teachers of biology use strategies in their classrooms which will further achievement in biology. The DEIBC instructional strategies address both oral and written discourse. The development of the DEIBC is especially timely for two reasons, firstly Matsubara (2010) has revealed that schools in Zambia struggle to provide science apparatus needed for practical activities and he suggested that educational development in Zambia and Africa at large should focus on verbal scientific interaction which does not require materials. Secondly, there is need to develop a scientific discourse which will improve classroom interaction between teachers and pupils. The DEIBC reference manual considers oral and written discourse as important aspects of science lessons to increase pupil's understanding in science. This is because learning science through oral and written discourse has been largely ignored (Hand $e t$ al 2003).

The DEIBC was field tested at Lubwe Secondary School and Samfya Secondary School. Five lessons were observed and ten pupils as well as five teachers were interviewed to determine ease of use and trustworthiness. It was discovered that the DEIBC promotes discourse through questioning and enhances pupil to pupil discussion. The DEIBC assists the teacher in identifying students prior Knowledge, this is because learning cannot be isolated from what pupils already know and that pupil's conceptual knowledge is influenced by everyday experiences with natural phenomenal and events (Das, 2013). Therefore teaching and learning should assess pupils' prior knowledge and modify instruction based on pupils' prior knowledge.

The DEIBC is divided into 3 phases namely the introductory phase, the main body phase and the conclusion phase.

Table3. Discourse engagement in biology classrooms: reference manual (DEIBC) Introductory phase

\begin{tabular}{|l|l|l|}
\hline \multicolumn{1}{|c|}{ ITEMS } & \multicolumn{1}{c|}{ WHAT SHOULD BE DONE } & \multicolumn{1}{c|}{ WHAT SHOULD NOT BE DONE } \\
\hline $\begin{array}{l}\text { Accessing pupils' } \\
\text { prior knowledge }\end{array}$ & $\begin{array}{l}\text { The lesson should begin with what pupils } \\
\text { already know }\end{array}$ & $\begin{array}{l}\text { Lesson begins without determining what } \\
\text { pupils already know }\end{array}$ \\
\hline $\begin{array}{l}\text { Conceptual } \\
\text { integration }\end{array}$ & $\begin{array}{l}\text { The teacher assists pupils in connecting } \\
\text { new knowledge with prior knowledge }\end{array}$ & $\begin{array}{l}\text { Lessons presented in isolation without } \\
\text { reference to previously learned concepts }\end{array}$ \\
\hline
\end{tabular}

Main body phase

\begin{tabular}{|l|l|l|}
\hline \multicolumn{1}{|c|}{ ITEMS } & \multicolumn{1}{|c|}{ WHAT SHOULD BE DONE } & \multicolumn{1}{c|}{ WHAT SHOULD NOT BE DONE } \\
\hline $\begin{array}{l}\text { Promotion of discourse } \\
\text { through questioning }\end{array}$ & $\begin{array}{l}\text { The teacher asks a question and gives } \\
\text { time to pupils to give the response }\end{array}$ & $\begin{array}{l}\text { The teacher asks a question and provides } \\
\text { the answer }\end{array}$ \\
\hline $\begin{array}{l}\text { Promotion of pupil to } \\
\text { pupil discussion }\end{array}$ & $\begin{array}{l}\text { The teacher organizes small groups } \\
\text { The teacher monitors pupil participation } \\
\text { in groups }\end{array}$ & $\begin{array}{l}\text { No pupil to pupil discussion } \\
\text { The teacher gives pupils work in groups } \\
\text { without planning and organizing activities }\end{array}$ \\
\hline
\end{tabular}

Conclusion phase

\begin{tabular}{|l|l|l|}
\hline \multicolumn{1}{|c|}{ ITEMS } & \multicolumn{1}{|c|}{ WHAT SHOULD BE DONE } & WHAT SHOULD NOT BE DONE \\
\hline $\begin{array}{l}\text { Promotion of teacher } \\
\text { explanation discourse }\end{array}$ & $\begin{array}{l}\text { The teacher summarises the lesson by explaining } \\
\text { the main points of the lesson to the pupils }\end{array}$ & $\begin{array}{l}\text { The teacher ends the lesson without } \\
\text { summarizing the main points }\end{array}$ \\
\hline $\begin{array}{l}\text { Provision of home } \\
\text { work }\end{array}$ & $\begin{array}{l}\text { The teacher gives pupils home work at the } \\
\text { end of the lesson }\end{array}$ & $\begin{array}{l}\text { The teacher ends the lesson without } \\
\text { giving pupils homework }\end{array}$ \\
\hline
\end{tabular}

Table4. Expected knowledge on mitosis, meiosis and classification of living organisms

Expected Knowledge on mitosis, meiosis and classification of living organisation

1. Stages of cell division in mitosis and meiosis (Refer to chromosomes and double strand of DNA).

2. Importance of mitosis and meiosis (Refer to growth and reproduction include uncontrolled cell division [cancer] ).

3. Types of plants- Chlorophytes (algae), Bryophypes (mosses, ferns), Conferous plants and flowering plants.

4. Types of animals-Reptiles, amphibians, birds, arthropods and protozoa.

5. Simple keys for classification (Refer to dichotomous keys).

6. Identify classes of vertebrates and common invertebrates using simple classification keys. 
Discourse Analysis of Lessons on Mitosis, Meiosis and Classification of Living Organisms at Selected Secondary Schools in Luapula Province, Zambia

\subsection{Interventions on mitosis, meiosis and classification of living organisms}

Five teachers were guided on the use of DEIBC based on the following five interventions on mitosis, meiosis and classification of plants, animals and Protista. The block diagrams below were given to teachers to act as a guide to pupils' group work and subsequent question and answer sessions during lessons on these perceived difficult topics.

\subsubsection{Intervention on Mitosis}

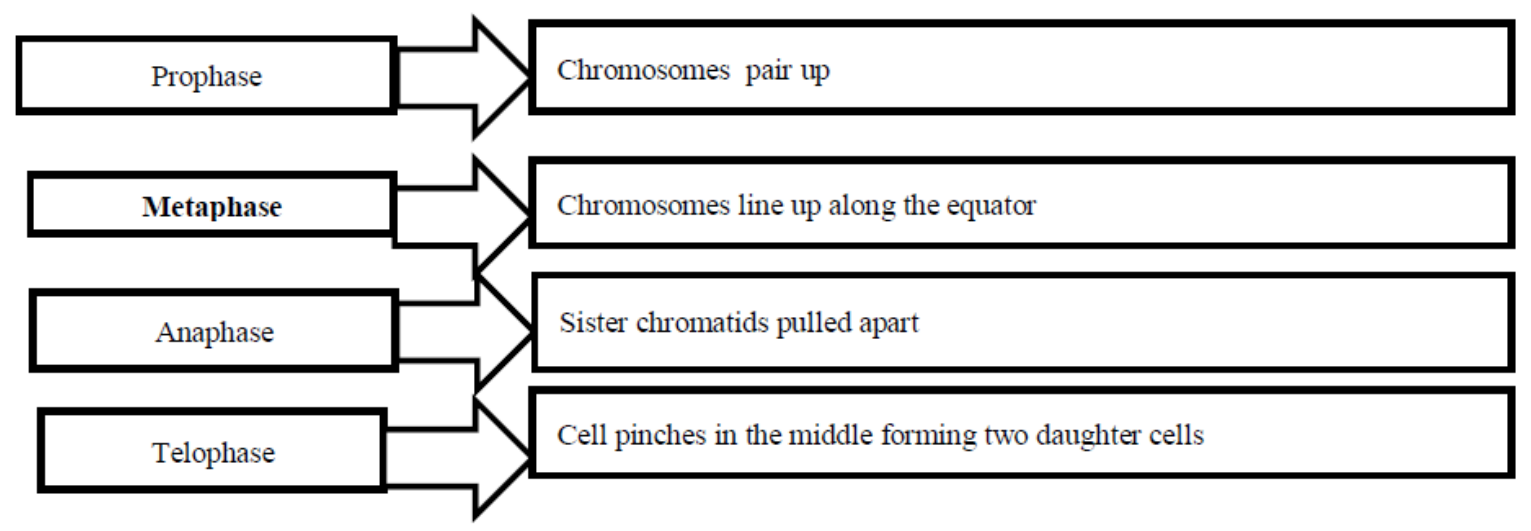

Figure9. Intervention on Mitosis

\subsubsection{Intervention on meiosis}
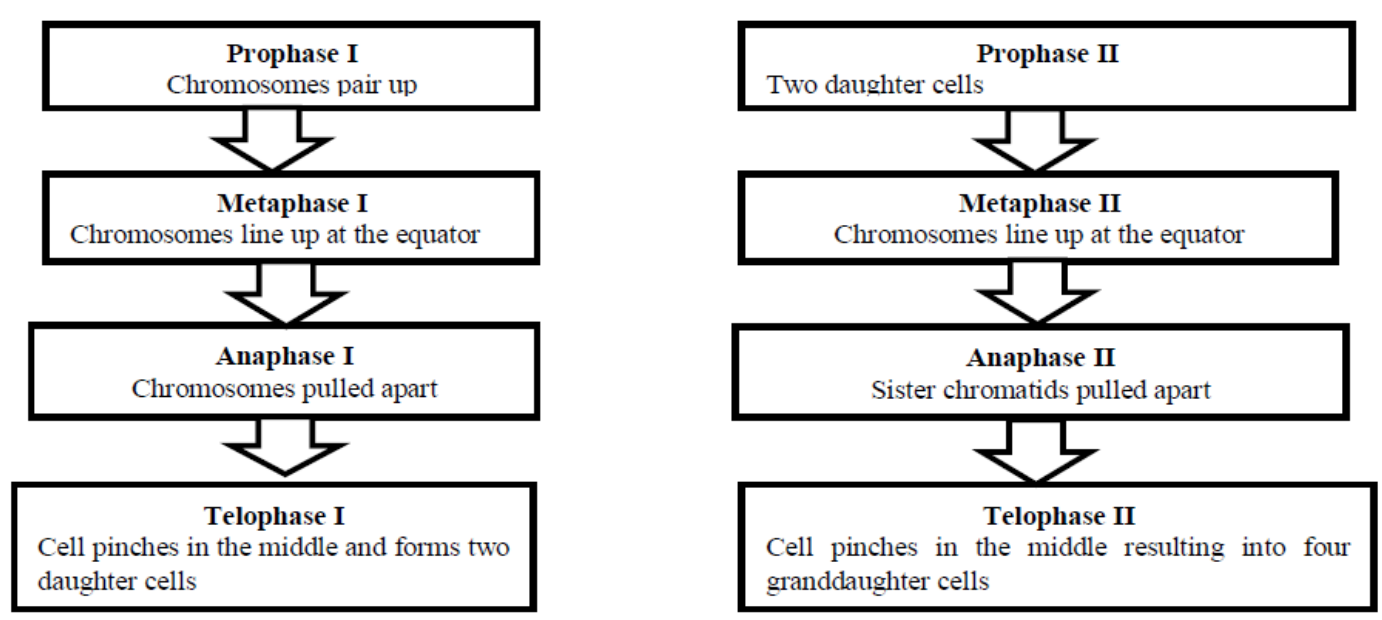

Figure10. Intervention on meiosis

\subsubsection{Intervention on classification of plants}

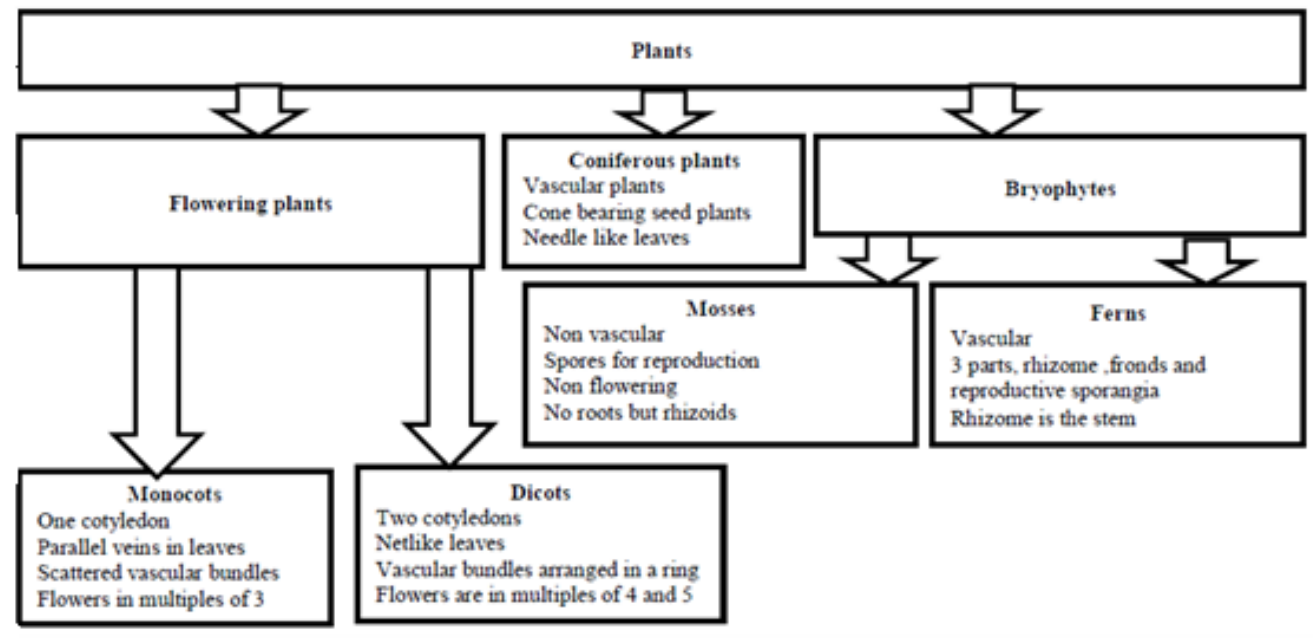

Figure11. Intervention on classification of plants 
Discourse Analysis of Lessons on Mitosis, Meiosis and Classification of Living Organisms at Selected Secondary Schools in Luapula Province, Zambia

\subsubsection{Intervention on Classification of Animals}

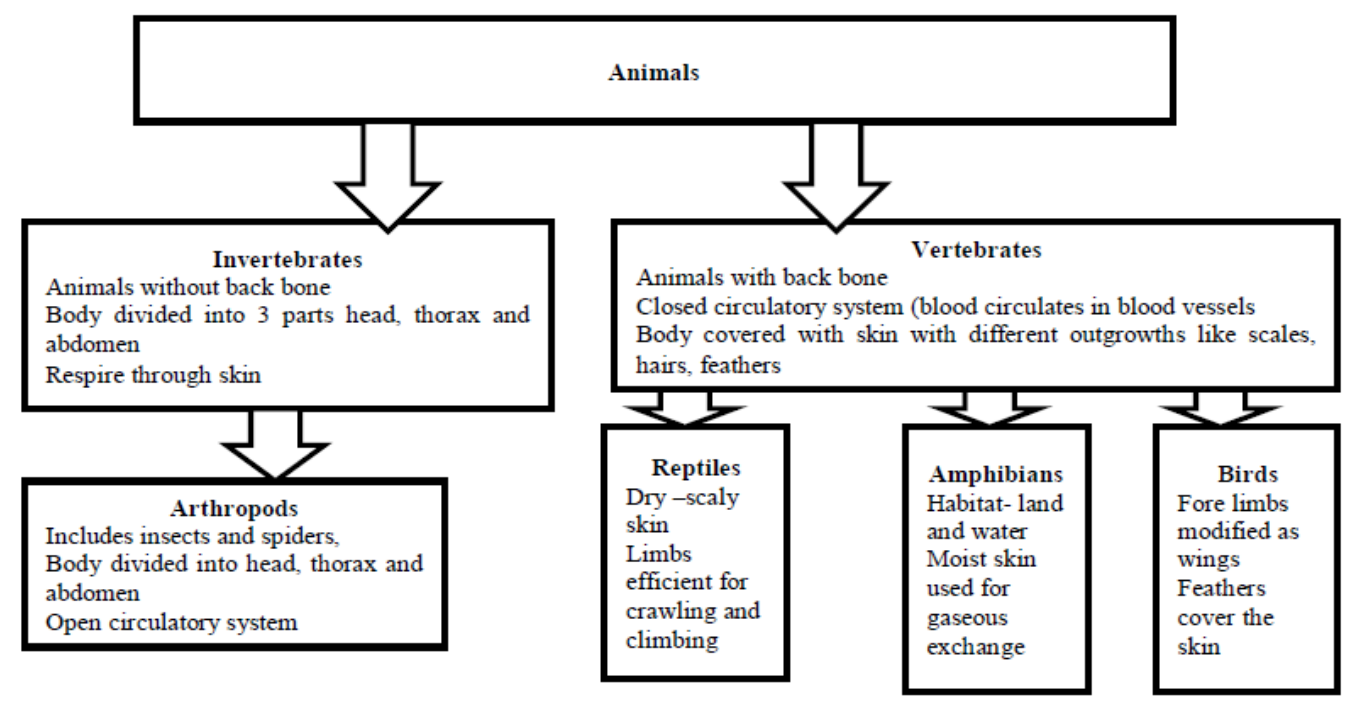

Figure12. Intervention on classification of animals

\subsubsection{Intervention on classification of Protista}

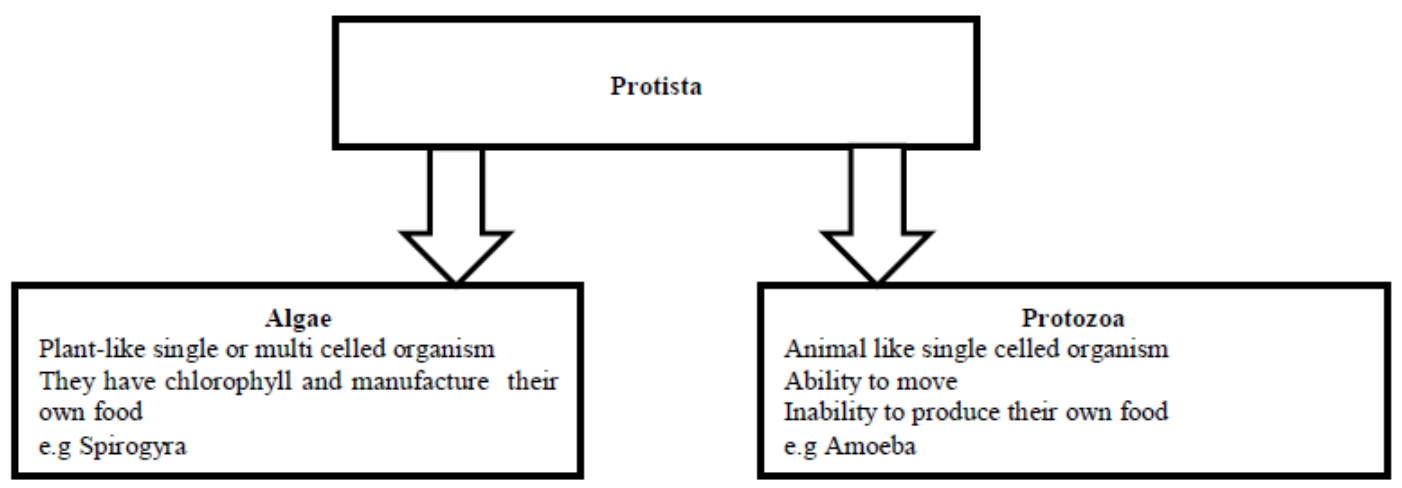

Figure13. Intervention on classification of Protista

\subsection{DEIBC Promotes Enhanced Understanding of Perceived Difficult Topics in Biology}

After implementing the DEIBC reference manual at two secondary schools some of the pupils who participated in the focus group discussions after the lessons had this to say:

I followed the lesson very well and it was easy for me to understand the stages of cell division due to the well organised group work which was given to us by the teacher.

Another pupil had this to say:

The introduction made me become interested in the lesson because it reminded me of mitosis.

So I easily connected mitosis to meiosis.

On the stages of cell division one pupil said that:

The work which was given to us by the teacher was very helpful because I could easily describe the stages of mitosis from the diagrams which were provided by the teacher.

Another pupil had this to say:

The teacher explained all the stages in summary form towards the end of the lesson. This made me remember most important points I forgot during the lesson.

The teachers who participated in the implementation of the DEIBC had this to say:

This manual is very useful because it guided me on what to avoid during my lesson presentation.

Another teacher had this to say:

The manual is very important because it is easy to follow and is very brief and clear. 
On the layout of the manual one teacher had this to say:

I enjoyed the lesson presentation because I knew what to do during the introduction, the main body and the conclusion.

Another teacher had this to say on pupil interest:

My pupils enjoyed the lesson very much because they were given clear instructions during group work.

\section{CONCLuSion}

The study has revealed discourse patterns used by teachers when teaching aspects of classification, mitosis and meiosis and their effects on pupils' understanding of these perceived difficult topics.

The study has shown that these misunderstandings are brought about by inadequate explanations, quick presentation of lessons, lack of practical activities and inappropriate group activities.

In view of the findings above, the following recommendations are made; teachers should combine the three discourse patterns namely teacher explanation, teacher led and pupil to pupil discourse patterns when teaching biology because these patterns proved effective when used together. Teachers should avoid using one discourse pattern during lessons on topics perceived to be difficult. Workshops and seminars should be organised for teachers to enable them acquire skills of teacher explanation, teacher led and pupil to pupil discourse patterns for teaching biology. Biological terms must be explained to pupils in a clear way by using the teacher explanation discourse pattern. Pupils should be encouraged to draw diagrams on cell division during pupil to pupil discourse pattern. Teachers must use real life examples of living organisms to help classify them into different kingdoms, phyla/divisions, classes, orders, families, genus and species during the teacher led discourse pattern.

\section{ACKNOWLEDGMENT}

This Ph.D research study could not have been possible without the tireless efforts of my well informed supervisors Dr C. Haambokoma and K. Nachiyunde.

\section{REFERENCES}

[1] Abimbola, I.O. (1998) "Teachers perception of important and difficult biology contents" Journal of functional education, 1(1), 10-21.

[2] Barnes, G., Mc Inerney, D.M \& Marsh, H.M. (2005). Exploring sex differences in science enrolment intentions: An application of the General Model of Academic Choice.The Australian Educational Researcher, 32 (2), 1-22.

[3] Beccles, C. (2012).Science teaching, classroom discussion and contexts in junior high schools in Ghana. $\mathrm{Ph}$.D. Thesis. Graduate school for international Development and co-operation: Hiroshima University.

[4] Chifwa, J. (2015). The teaching of Genetics in selected secondary schools in Kitwe District, Zambia. Med (Science Education) Thesis, Lusaka: UNZA.

[5] Chocha, S.E, Namayanga, K.C., \& Ndhlovu, H.G. (2014). Teaching Science Practically: An assessment of Teacher competences on O-Level biology practical work in Zambia.Policy, Zambia Journal of Teacher professional growth. 2(1) 26-38.

[6] Cimer, A. (2012). What makes biology learning difficult and effective: Student's views.Education Research and Reviews? 7(3), 61-71.

[7] Creswell, J.W. (2003).Research Design: qualitative, quantitative and mixed methods approaches. Thousand Oaks, California: SAGE Publications.

[8] Das, R.C. (2013). Science teaching in Schools. New Delhi: Sterling publishers private limited.

[9] Eccles, J.S., Jacobs, J.E and Harold, R.D (1990). Gender role stereotypes, expectancy effects and parents socialisation of gender differences. Journal of Social Issues, 46, 186-201

[10] Eccles, J., Barber, B. \& Jozefewiez, D. (1999). Linking gender to educational, occupational and recreational choices: Applying the Eccles et al model of achievement- related choices, In W.B swann, J.H. Langlois and L.A .Gilbert (Eds.), Sexism and Stereotypes in Morden Society: The Gender Science of Janet Taylor Spence (pp. 153-192). Washington, DC. American Psychological Association.

[11] Eccles, J.S \& Wigfield, A (2002) Motivational beliefs, values and goals. Annual Review of Psychology, 53, 109-132. 
Discourse Analysis of Lessons on Mitosis, Meiosis and Classification of Living Organisms at Selected Secondary Schools in Luapula Province, Zambia

[12] Giaconia, R., \&Hedges, L. (1982). Identifying features of effective open education. Review of Educational Research, 52, 579-602

[13] Examination council of Zambia. (2004). Examination performance review, Lusaka: ECZ.

[14] Examination council of Zambia. (2008). Examination performance review, Lusaka: ECZ.

[15] Examination council of Zambia. (2016). Examination performance review, Lusaka: ECZ.

[16] Haambokoma,C. Nkata, B. Kostyuk, V.S. Chabalengula, V. Mbewe, S. Tabakamulamu, M. Ndhlovu, Z.B. Mushanga, R. and Nthani, D. (2002). Strengthening of Mathematics and Science Education in Zambian Secondary schools: Baseline Study, Lusaka: J.I.C.A.

[17] Haambokoma, C. (2007). Errors pupils make in the biology practical test of the school certificate examination. Proceedings of the $15^{\text {th }}$ annual conference of the southern African Association for research in mathematics, science and technology education, 1.

[18] Haambokoma, C. (2015). Influences on female pupils' decision to join the Junior Engineers, Technicians and Scientists Club in Selected Schools in Zambia. Ph.D. Thesis. Norwegian University of Life Sciences.

[19] Huitt, W. (1995). A systems model of the teaching and learning process.Educational psychology interactive. Valdosta, G.A: college of Education, Valdosta state university.

[20] Kelly,G.A.,(1966). A brief introduction to Personal Construct Theory in :Paszkowska-Rogacz, A. and Z. Kabzinska. (2012). Personal Construct Theory to Vocational Guidance, Research, ISSN 2159-5542, 2 (7), 408-421, Davind Publishing, Lodz, Poland.

[21] Kombo, D. K., \& Tromp, D. L. A. (2006). Proposal and thesis writing. An introduction, Nairobi, Paulings Publications Africa.

[22] Matsubara, K. (2010). Development of lesson analysis system for student- centred science teaching towards international cooperation. New perspectives in science education.

[23] Musonda, M. (2013).Topics in biology perceived as difficult to learn; Un published MED (Science Education) Thesis, Lusaka: University of Zambia.

[24] Merriam, B.S. (1998). Qualitative research and case study applications in education. San Francisco: Jossey-Bass Inc. publishers.

[25] Mudenda, V. (2008). Zambian grade twelve pupils experiences of biology practical work during school certificate examinations. The case for Kabwe high school; An un published M E D (Science Education) Thesis, Lusaka: University of Zambia.

[26] Mwiya, P. (2015). The classroom performance of graduate and non-graduate teachers: A case of selected secondary schools in Lusaka district. Un published MED thesis, Lusaka: University of Zambia.

[27] PEO, Mansa. (2016). Grade 12 examination analysis, Mansa: PEO.

[28] Rosenshine, B. (1995). Advances in research on instruction.The Journal of Educational Research, 88(5), 262-268.

[29] Slavin, R.E. (1995). Cooperative learning and intergroup relations. In j. Banks (Ed), Handbook of research on multicultural education. New York: Macmillan.

[30] Stuart, M.E \& Whaley, D.E (2005). Resistance and persistence: An Expectancy-value approach to understanding women's participation in a male- defined sport. Women in sport and physical activity Journal.

[31] Von Glasersfeld .E (1995) Radical constructivism: A way of knowing and learning, London; The Falmer press.

[32] Wigfield, A. (1994). The role of Children's achievement values in the self-regulation of their learning outcomes. In D.H. Schunk and B.J. Zimmerman (Eds), self-regulation of learning and performance: Issues and Educational applications 101-124. Mahwah, NJ: Erlbaum.

[33] Xiang, P., Mc Bride, R., Guan, J. \& Solmon, M, (2003). Children's Motivation in Elementary Physical Education: An expectancy-Value Model of achievement choice. Research quarterly for exercise and sport.

\section{AUTHOR'S BIOGRAPHY}

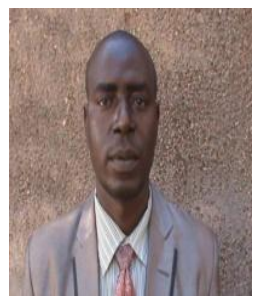

Mr Kambi Manda is a Ph.D candidate in Science Education at the University of Zambia in the Department of Mathematics and Science Education. Currently he is Head of Department for Natural Sciences at Lubwe Secondary School in Luapula Province of Zambia and works as a part time Lecturer at Chalimbana University. 
Discourse Analysis of Lessons on Mitosis, Meiosis and Classification of Living Organisms at Selected Secondary Schools in Luapula Province, Zambia

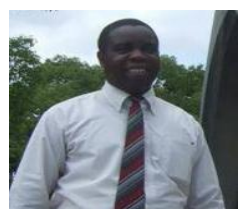

Dr Christopher Haambokoma is a senior Lecturer of biology education at the University of Zambia in the Department of Mathematics and science Education. $\mathrm{He}$ holds a Ph.D in Science Education from the Norwegian University of life sciences.



Dr Kabunga Nachiyunde is a lecturer of Chemistry Education at the University of Zambia in the Department of Mathematics and Science Education. He holds a Ph.D in Chemistry Education from Hiroshima University in Japan.

Citation: Kambi Manda, Christopher Haambokoma, Kabunga Nachiyunde. " Discourse Analysis of Lessons on Mitosis, Meiosis and Classification of Living Organisms at Selected Secondary Schools in Luapula Province, Zambia." International Journal of Humanities Social Sciences and Education (IJHSSE), vol 5, no. 7, 2018, pp. 36-55. doi: http://dx.doi.org/10.20431/2349-0381.0507006.

Copyright: () 2018 Authors. This is an open-access article distributed under the terms of the Creative Commons Attribution License, which permits unrestricted use, distribution, and reproduction in any medium, provided the original author and source are credited. 